\title{
Urban Living Labs for Sustainability in Suburbs in Need of Modernization and Social Uplift
}

\author{
Katarina Buhr, Maija Federley, and Anja Karlsson
}

\author{
" People worry about costs addressing sustainability") \\ in less valued suburbs, but what are the costs of \\ not responding to the residents' concerns about \\ their living environment?
}

Environmental investigator

Botkyrka Municipality of Sweden

\begin{abstract}
A number of urban living labs have been set up in recent years, with the aim of developing innovation processes within a multi-stakeholder partnership in an urban context. Several urban living labs focus on sustainable development, which is a visible and urgent issue in less valued suburbs in need of modernization and social uplift. We argue that, when applying the living labs approach in the context of sustainable development in suburbs, the primary focus should be society's collective goals, as expressed through municipalities and users. The aim of this article is to show examples of how urban living labs can be applied in less valued suburbs in order to contribute to sustainability based on societal goals. We build on analyses from the research project SubUrbanLab, where urban living labs were set up in Alby and Peltosaari, two suburban areas in Sweden and Finland, respectively. We draw lessons regarding how to use urban living labs for sustainable development in order to create favourable conditions for ongoing engagement with the municipality and users towards long-term sustainability.
\end{abstract}

\section{Introduction}

A number of urban living labs have been set up in recent years, with the aim of developing innovation processes within a multi-stakeholder partnership in an urban context (cf. JPI Urban Europe 2015a; Juujärvi \& Pesso, 2013; McKormick \& Kiss, 2015; Voytenko et al., in press). Urban living labs go beyond engaging urban stakeholders and residents, as suggested by other usercentered or participatory research approaches, in that various stakeholders are partners throughout the cocreative process. Urban living labs offer opportunities to develop the city together with residents and other stakeholders in a real-life context in a way that responds to the needs of the users (Mulder, 2012). Among the urban living labs to date, several have focused on sustainable development (HSB Living Lab, 2015; Voytenko et al., in press). In the words of Allen, McKeever, and Mitchum (1996), a sustainable community is created through "the deliberate effort to ensure that community development not only enhances the local economy, but also the local environment and quality of life". This definition emphasizes the local dimension of the three conventional sustainability pillars. In practice, many cities and municipalities have operationalized what sustainability means to them and what aspects are considered particularly important to address (e.g., Botkyrka Municipality, 2009).

Many sustainability issues are highly visible in numerous suburbs across Europe that were built in the 1960s and 1970s and are characterized by outdated urban systems in urgent need of modernization and social uplift. These suburbs share many challenges related to local aspects of sustainability and quality of life, which makes it relevant to speak of suburban sustainability. In general, the population of these less valued suburbs is relatively demographically homogenous in terms of, for example, income level, education level, and social background, although they may represent a range of ethni- 


\section{Urban Living Labs for Sustainability in Suburbs in Need of Modernization and Social Uplift} Katarina Buhr, Maija Federley, and Anja Karlsson

cities. Segregation often becomes obvious, as marginalized groups live largely separated from other societal groups - this situation is sometimes reinforced by poor transport solutions that cut off an area from other parts of the city. It is also common that poor urban planning and lack of modernization has contributed to perceptions of unsafe urban environments. Moreover, the buildings themselves often have high energy consumption and lack modern technology that could have limited their negative environmental impacts. Massive renovation of these urban areas is required, but investment opportunities are often quite limited. Modernizing these suburbs in a sustainable way will not only require comprehensive investments in advanced technology but also must take into account social, ecologic$\mathrm{al}$, and economic objectives. Urban living labs offer opportunities to bring existing groups of urban actors together in new ways to allow for local sustainable development (Voytenko et al., in press), thereby responding to calls for methods and arenas that promote stakeholder collaboration and learning in urban development (Elbakidze et al., 2015). Urban living labs can develop suburbs through an advanced form of stakeholder and resident involvement, which may increase the chances that modernization actions contribute to sustainability in a way that resonates with local people's ideas and needs.

Many living labs have been used to test information and communication technology (ICT) and services (e.g., Følstad, 2008) and have featured companies with commercial goals or educational institutions with research goals as a main driver. One research branch uses living labs to study "smart cities" (Hirvikoski, 2014; McPhee et al., 2015), often with a focus on ICT such as digital development services (Eskelinen et al., 2015). However, many urban living labs do not serve as company-driven technological research environments, but rather as platforms for citizens to participate in city planning (Juujärvi \& Pesso, 2013). Voytenko and colleagues (in press) found that, among five major European urban living lab projects that address sustainability, private sector involvement was not particularly salient. Although business has an important role to play in sustainable development, we focus in this article on how contributions to sustainability in less valued suburbs can be made without or with only minimal commercial goals.

We argue that, when applying a living labs approach with sustainability objectives in less valued suburbs, we should first and foremost start with the collective goals of the society, expressed through municipalities and the users themselves, while acknowledging the goals of all participants. Urban living labs offer an excellent platform to develop less valued suburbs in a sustainable direction through multi-stakeholder collaboration. Against this backdrop, the aim of this article is to show inspiring examples of how urban living labs can be applied in less valued suburbs, starting from the society's collective goals, in order to respond to local sustainability challenges. In line with previous research on the early development of living lab methodologies (Ståhlbröst, 2008), we focus on the design phase of the urban living labs. Our article also contributes to the growing collection of empirical studies of urban living labs (e.g., Juujärvi \& Pesso, 2013; Veeckman et al., 2013; Voytenko et al., in press). We share lessons learned and hope to inspire others to use living labs to contribute to suburban sustainability.

\section{Living Labs in a Suburban Context}

There is no generally accepted definition of living labs (Leminen, 2015; Westerlund \& Leminen, 2014), but they are frequently described as consisting of elements of cocreation, exploration, experimentation, and evaluation (e.g., ENoLL, 2015). Leminen (2015) emphasizes that living labs are used by communities and for innovation. An urban living lab has been defined as "a forum for innovation, applied to the development of new products, systems, services, and processes in an urban area; employing working methods to integrate people into the entire development process as users and co-creators to explore, examine, experiment, test and evaluate new ideas, scenarios, processes, systems, concepts and creative solutions in complex and everyday contexts" (JPI Urban Europe, 2015b). Rather than repeating previous reviews of various definitions, we explain below how two key ingredients of urban living labs - citizens and innovation - were operationalized in the context of this research.

In an urban perspective, it is common to refer to citizens as important co-creators (e.g., Eskelinen et al., 2015; Hirvikoski, 2014; Juujärvi \& Pesso, 2013). Citizens include residents as well as other people who spend time in the area, through work, school, leisure activities, etc., and stakeholders who are concerned with or may be affected by an activity there. With regards to innovation, we apply a broad perspective in the sense that it is not necessarily a brand new product or service, but rather a new valuable solution in a particular context. To illustrate this perspective, the use of the living labs approach in an urban context is relatively new, but it is innovative to use living labs in the context of ad- 


\section{Urban Living Labs for Sustainability in Suburbs in Need of Modernization and Social Uplift}

Katarina Buhr, Maija Federley, and Anja Karlsson

dressing sustainability issues in less valued suburbs. Although participatory methods have been used in these suburbs before, urban living labs go well beyond common dialogue practices.

Urban living labs can be initiated by various actors (Voytenko et al., in press), and it has been suggested that the type of actor that drives the activities within a living lab affects its characteristics. Leminen, Westerlund, \& Nyström (2012) distinguished between four types of living labs depending on the driving actor: i) utilizer-driven living labs, which are driven by companies to develop their business; ii) enabler-driven living labs, which typically are public sector projects built around regional development objectives; iii) providerdriven living labs launched mainly by developer organizations such as educational institutes, universities or consultants, to promote research and knowledge creation; and iv) user-driven living labs established by the user community itself, focusing on solving specific problems for the users and benefitting other stakeholders only indirectly. We find this distinction useful in that it highlights how living lab objectives are intimately linked with the driving actors and their essential goals.

When applying living labs focusing on sustainability in suburbs that are in need of modernization and social uplift, it makes sense to start with a focus on the collective goals of the society (i.e., municipalities and users). It can be a way to address important sustainability issues that often fall outside the responsibility and interest of single actors, such as creating meaningful and inexpensive activities for residents and improving the safety and appreciation of public spaces. Although these issues are typically on the agenda of public authorities, there is an added valued when involving additional actors through a living lab approach. Also, urban living labs are often closely linked to city development processes that normally span several years and therefore need long-term commitment to achieve their full potential (Juujärvi \& Pesso, 2013).

We argue that there are at least three reasons why living labs are a useful approach to address sustainability challenges in suburbs in need of modernization and social uplift. First, many of these suburbs face major modernization measures both in the indoor and the outdoor environments (Häkkinen, 2012), and living lab methods increase the chances of gaining broad support for such large changes. Second, taking users' ideas into account in urban development increases the chances of users valuing, taking pride in, and appreciating the at- tractiveness of their local area, which is beneficial for these suburbs. And, third, living lab methods can support interaction between municipalities and residents, giving residents a feeling that they are being listened to, which may be particularly important in suburbs where a relatively large share of the population can be described as marginalized. Engaging residents in urban development can in itself be a way to contribute to social sustainability (Weingaertner \& Moberg, 2011).

\section{Case Studies from Alby and Peltosaari}

This article builds on analyses from the JPI Urban Europe research project SubUrbanLab (http://suburbanlab.eu), in which researchers from VTT Technical Research Centre of Finland and IVL Swedish Environmental Research Institute cooperated with the municipalities of Botkyrka and Riihimäki to set up urban living labs in two suburban case areas located in the outskirts of the capitals of Sweden and Finland, respectively (cf. Thörn et al., 2015).

The Peltosaari neighbourhood is located next to Riihimäki city centre, north of Helsinki, Finland, and has approximately 3,000 residents. The buildings in Peltosaari represent typical concrete apartment buildings constructed during the 1970s and 1980s. A large share of the municipality's social housing is located in Peltosaari and the population structure is biased, with a considerably larger share of unemployed, low-income households and residents with lower educational levels than average in Riihimäki. The challenges in the area include the physical condition of buildings, low interest from private investors, social problems and general untidiness. The market prices of the apartments in the area are remarkably lower than in other areas with similar locations close to railway stations and services. On the positive side, Peltosaari is known for its many activities organized by volunteer residents and its laid-back atmosphere.

The Alby neighbourhood of the Botkyrka municipality is a suburban area in the south of Stockholm, Sweden, with around 13,300 inhabitants (Botkyrka Statistikportal, 2015). The housing stock in Alby was built in the early 1970s, during a time when approximately one million new dwellings were built in Sweden due to new living standards and an increased demand for apartments. The area is characterized by large-scale uniform buildings and sterile public spaces. Like many other neighbourhoods built during this time, Alby is in urgent need of comprehensive renovation and renewal of both the housing stock and its surroundings. One im- 


\section{Urban Living Labs for Sustainability in Suburbs in Need of Modernization and Social Uplift} Katarina Buhr, Maija Federley, and Anja Karlsson

portant challenge is to bring the housing up to today's environmental standards and needs. The area also faces considerable social challenges, such as high unemployment rates and segregation, and is at the same time constrained by a lack of economic resources. Approximately $60 \%$ of the inhabitants originate from other countries than Sweden (Botkyrka Municipality, 2015). Alby is located in a part of Botkyrka where citizens have expressed that they do not feel secure in public spaces (SCB, 2015). However, Botkyrka is also famous for its rich cultural life with a salient artistic vibe.

Both Peltosaari and Alby have previous experiences of involving the citizens in their decision-making, for example through dialogue forums in Alby and "Peltosaari Parliament" in Peltosaari, but it has been challenging to receive commitment from broad and representative groups of residents (Thörn et al., 2015). Urban living labs offer a possibility to test new working methods, but it is important to carefully consider how they can be designed in order to contribute to the suburbs' sustainability challenges and how to make participation rewarding for the stakeholders. In the following section, we show examples of these opportunities and challenges by describing two of the six urban living labs carried out in the research project SubUrbanLab.

\section{Alby (Sweden): New Light on Alby Hill}

The "New Light on Alby Hill" living lab was set up to contribute to local sustainability by transforming a walkway lined by vegetation that residents had previously identified in surveys as insecure. The walkway is one of the few stretches through which residents can ac-

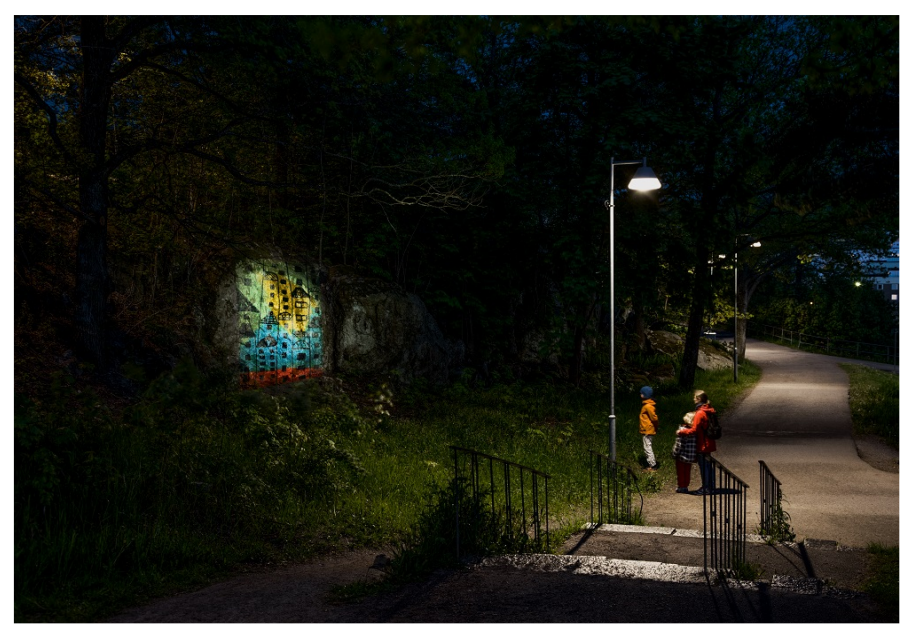

cess public transportation and downtown from the residential area of Alby Hill. We set up new LED technology along the walkway and four so-called "Gobos", which allowed for artistic decoration through light installations to be projected on two rock walls and two spots in the grass near the walkway (Figure 1). LED technology is energy efficient and inexpensive and was in this project used as a way to allow light to be distributed over a larger area to increase the residents' sense of security, as compared to the existing lighting conditions. The images used as artistic decorations on the rock walls and spots in the grass were drawings submitted by local residents and elementary school students on the theme "Our Alby". In this way, the artistic decorations gave a voice to the users of this walkway, while highlighting the surroundings. Out of 20 images submitted by residents, two images were selected by a jury of local stakeholders and two images were selected by residents via an Internet-based poll. Three of the selected images gave expression to anti-racism messages.

"New Light on Alby Hill" was designed to address several sustainability challenges that are typical for many less valued suburbs, such as the perceived lack of security in public spaces, old-fashioned lighting with relatively large energy consumption, lack of aesthetic public spaces, unattractiveness of public transport, and need for meaningful activities for youth. These are important issues that fall mainly under the responsibility of the municipality, which is why Botkyrka municipality participated in dialogue with residents from the start. Several of these sustainability challenges had previously been identified by Botkyrka Municipality and were formalized as goals in their program for sustainable de-

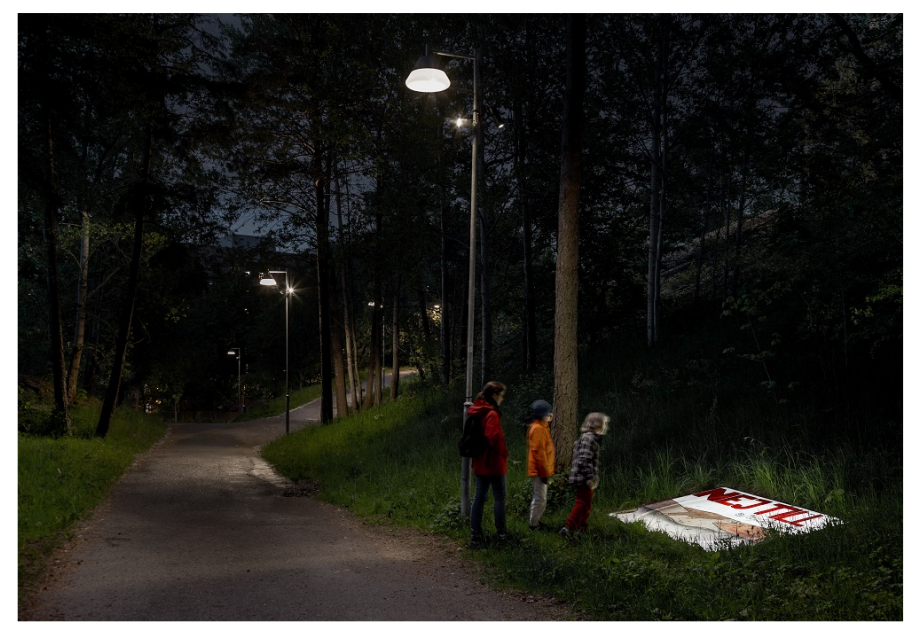

Figure 1. Artistic decorations on rock walls and spots in the grass along the walkway in Alby Hill (Photo credit: Olof Thiel). 


\section{Urban Living Labs for Sustainability in Suburbs in Need of Modernization and Social Uplift} Katarina Buhr, Maija Federley, and Anja Karlsson

velopment (Botkyrka Municipality, 2009). This work already built on dialogue with local residents, and within "New Light on Alby Hill", the needs and ideas of local residents were further explored and taken into consideration. Residents - the main users of this walkway participated in the urban living lab through, for example, the Alby Hill Residents' Council, a private housing company (Mitt Alby), and a local school. The residents were particularly involved in the planning of the project and the design of ambient light, although everyone had the opportunity to submit drawings and vote on what drawings they would like to see projected along the walkway. Lighting designers, local entrepreneurs, and landscape architects supported the technical aspects of the urban living lab, and researchers at the IVL Swedish Environmental Research Institute both supported and studied the process, although product development or knowledge creation was never their main focus. Methods used included an interactive website and different channels for information, open Internet-based polls, and regular meetings between the municipality, the housing company, and the researchers. In summary, "New Light on Alby Hill" allowed for an innovative co-creation activity to renew a walkway in Alby that will be better appreciated by its users.

\section{Peltosaari (Finland): Together More}

The aim of "Together More" was to improve people's appreciation of Peltosaari and strengthen social cohesion. These were important priorities for the City of Riihimäki, which was a driving actor behind the urban living lab from the start. The municipality built on the identified needs of the community, striving to enable activities run by third parties and let users take responsibility over them to support continuity. Providing methodological support for the urban living lab, the research institute VTT performed a survey at the beginning of the lab to explore the needs and ideas of the citizens of Peltosaari who were the users of public services in the area. The citizens expressed that meaningful and lowcost activities were needed for youth and families with children, for example, but so far, these groups had been difficult to engage. Activities across groups, such as senior citizens, children, immigrants, and the unemployed, were also needed to increase the communal feeling, as well as improved dialogue between the municipality and residents. Another challenge in Peltosaari was that several residents had experience of being involved in previous development projects where they felt frustrated with the uncertainty of implementation and few visible improvements.

“Together More" became an umbrella to implement two types of activities, both of which had been identified on the basis of local development priorities and user interests. First, a former grill kiosk was renovated in a central location to create a meeting place that would act as a "living room" for local residents (Figure 2). The venue was made available free of charge for potential leaders of leisure activities, and it offered selected municipal services. Second, a range of events and activities were organized, such as senior gymnastics, urban gardening, a multicultural café, school break activities for children, the building and opening of a fishing place, and a mid-summer party (Figure 2). Several of these events and activities were set up so that people could spontaneously join in, which reached all kinds of people, including youth and families with children. The urban living lab coordinated facilities, events, and people and supported the implementation of these activities. What these activities had in common was the aim of improving appreciation of the area and strength-

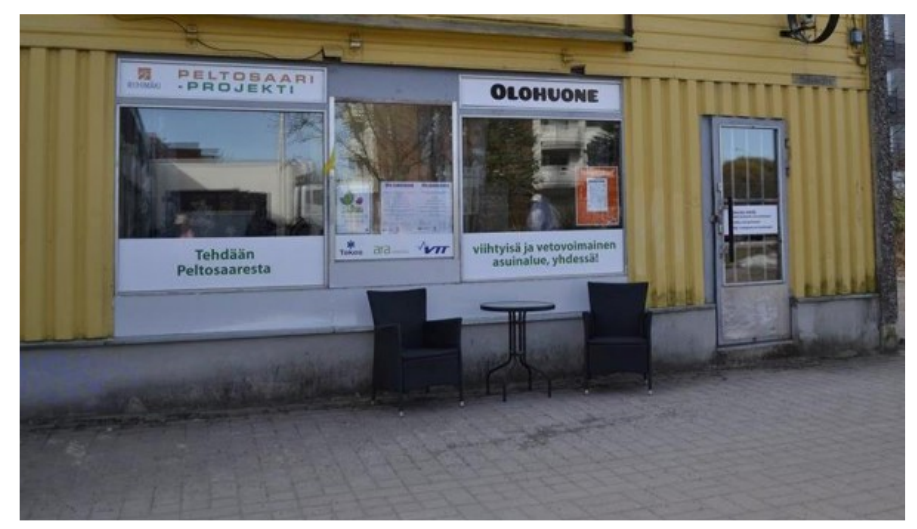

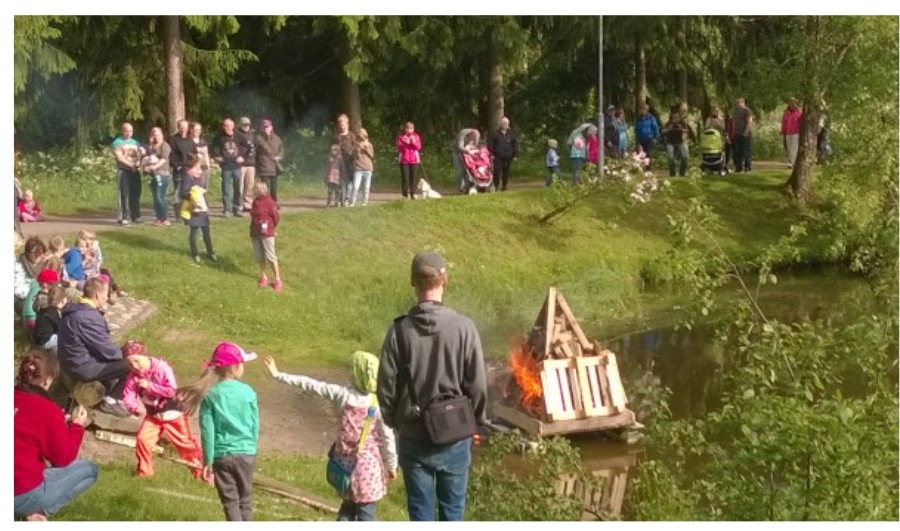

Figure 2. Midsummer celebrations and "living room" for local residents in Peltosaari (Photo credit: Ilari Seitsonen). 


\section{Urban Living Labs for Sustainability in Suburbs in Need of Modernization and Social Uplift}

Katarina Buhr, Maija Federley, and Anja Karlsson

ening social cohesion, hence addressing sustainability challenges that are common in less valued suburbs, such as segregation, loneliness, inequality, and frustration among citizens - phenomena that also lead to increased social costs and decreased welfare among citizens. There are important issues for the society and it is in the interest of the public sector, including municipalities, to address them.

"Together More" was planned, designed, and implemented on the basis of the priorities of the City of Riihimäki and residents, who expressed themselves through third sector organizations, the "Peltosaari Parliament" and the "Peltosaari Association", as well as directly through a range of dialogue fora organized by researchers at VTT. Some of the activities were launched in co-operation with other concurrent projects of the municipality, such as "Youth First", which offered personalized support for youth employment, and "Liikuta" and "Kulttuuriviritys", which organized cultural activities for local residents, such as urban gardening. This deliberate strategy by the municipality was designed to reach and engage more people. VTT organized an early survey sent out to residents in which prioritized areas for development were identified, discussion events in which users were encouraged to influence the plans, face-to-face discussions with residents that participated in the activities, and meetings with the Peltosaari Parliament and the Peltosaari Association. Facebook, Twitter, and Instagram accounts were established to further improve communication about the events and observations in Peltosaari. In summary, "Together More" launched processes for co-creating a more attractive neighbourhood that would appeal to residents, visitors, and other stakeholders.

\section{Conclusion}

We have shown examples of how urban living labs in less valued suburbs can contribute to sustainability based on societal goals (i.e., the goals of municipalities and users), building on analyses from two urban living labs in Alby and Peltosaari. Both urban living labs should be regarded as a combination of enabler-driver and user-driven living labs (cf. Leminen et al., 2012), given that societal goals were primarily derived from the goals of municipalities and users. The networks formed around municipalities and users, rather than around the research institutes or other stakeholders. Key purposes revolved around local development objectives and problem-solving for the community, not around research and knowledge creation or commer- cial goals. To conclude, we draw lessons about how urban living labs can be applied in a suburban sustainability context in order to create favorable conditions for: i) municipality and user engagement and ii) continuation towards long-term sustainability.

Applying urban living labs in two different countries allows for insights that may otherwise have passed unnoticed. Besides cross-national learning throughout the process, at least two observations regarding the co-creation part in the design phase deserve attention. As many living labs have noticed, engagement among users should not be taken for granted even though the activities focus on improving their everyday lives (e.g., Veeckman et al., 2013). The experiences from Alby and Peltosaari suggest that user engagement can be spurred by addressing sustainability challenges that are particularly salient in the suburb and allow people to express themselves on issues that already engage and interest them. "New Light on Alby Hill" was designed not only to improve the outdoor illumination and the sense of security, but also to draw on the esthetic "vibe" that exists there. With no steering, a significant share of the contributions, expressed through art, came to focus on anti-racism messages: a salient issue in Alby, which has a large proportion of immigrants. The Peltosaari-based urban living lab "Together More" was designed to enhance appreciation of the area and strengthen social cohesion. The urban living lab took advantage of the laidback Peltosaari spirit by developing activities that people could spontaneously join into, such as urban gardening, the multicultural café, fishing, and midsummer celebrations. These activities also fulfilled the wish among citizens to improve tidiness of the area and enhance dialogue with the municipality. Both urban living labs experienced enhanced user engagement by launching activities with visible results in public spaces that allow for long-term continuation.

To spur municipality engagement, one needs to take into consideration the institutional and cultural preconditions when introducing the living lab approach. Even though the municipalities involved had previous experience of dialogue with citizens, they had to challenge and expand their idea of co-creation into something more extensive. In public organizations, challenges of communication, collaboration, and coordination between departments may be more evident compared to the private sector. Different departments may face different demands and have different goals. Also, the cross-national comparison revealed different traditions with regards to ideas about the extent to which residents should be involved in decision making. 


\section{Urban Living Labs for Sustainability in Suburbs in Need of Modernization and Social Uplift} Katarina Buhr, Maija Federley, and Anja Karlsson

The issue of long-term continuation of the living lab initiatives may be particularly challenging when the urban living lab is based on societal goals and with few commercial objectives yet is important in light of the pressing sustainability issues in many suburbs. The urban living labs presented here paved the way for long-term continuation by setting up facilities and improving social relations, both of which need maintenance. In addition, both urban living labs need involvement of the municipality in order to continue, although it does not necessarily have to be the driving actor. In the case of "New Light on Alby Hill", the municipality owns the walkway and the lightning, but the drawing contest can be delegated to the users of the walkway. In a similar vein, "Together More" offered a venue, or "living room", free of charge thanks to the municipality, but many activities could be run by residents. If the urban living labs are transformed into user-driven urban living labs primarily run by the residents, it may further strengthen residents' feelings of inclusion and participation in the local society. But, residents may not have the time, interest, knowledge, and skills to drive a living lab. On the other hand, an enabler-driven urban living lab, run by the municipality, may increase the chances of sufficient resources; however, the working methods of living labs need to be fully embraced and integrated into existing organizational routines. Experiences from "Together More" also show that residents valued the municipality's initiatives to co-create activities that would improve social cohesion and the general appreciation of Peltosaari. The research project SubUrbanLab offers additional lessons from six urban living labs that can provide further inspiration to continue exploring the opportunities for such labs to address sustainability in less valued suburbs.

\section{Recommended Reading}

This article builds on the research project SubUrbanLab, funded by VINNOVA and Tekes through Joint Programming Initiative - Urban Europe, 2013-2016. The project includes six urban living labs based in Alby and Peltosaari. Information and reports from the project, and each urban living lab, is available at suburbanlab.eu

\section{About the Authors}

Katarina Buhr is a Social Scientist at IVL Swedish Environment Research Institute. She holds a PhD in Business Administration (Organization and Management) from Uppsala University in Sweden and has been a post-doctoral researcher at Linköping University in Sweden. She has worked in several research projects related to urban sustainable development and has published widely on policy processes and public engagement in the environmental and sustainability field. In SubUrbanLab, she was particularly involved in the evaluation and scientific writing activities for the urban living labs in Alby, Sweden.

Maija Federley is a Senior Scientist at VTT Technical Research Centre of Finland. She holds a Master of Science degree in technology from Helsinki University of Technology (currently Aalto University) in Finland. She has worked in several research projects related to co-development of digital services and environmental sustainability communication in stakeholder networks. In SubUrbanLab, she was particularly involved in designing and observing all urban living labs in Peltosaari, Finland, with a special interest in participatory methods and development of urban living lab practices and evaluation.

Anja Karlsson has worked at IVL Swedish Environment Research Institute since 2011. She holds a BSc in Political Science and Environmental Science from Gothenburg University, Sweden and an MSc from Uppsala University, Sweden. Her studies have focused on stakeholder and public participation in local and national decision making. She has worked in research projects related to sustainable development in urban areas, focusing on social sustainability and the involvement of residents and other stakeholders in urban development. In SubUrbanLab, she was particularly involved in the urban living labs in Alby, Sweden, and the evaluation of the urban living labs. 


\section{Urban Living Labs for Sustainability in Suburbs in Need of Modernization and Social Uplift Katarina Buhr, Maija Federley, and Anja Karlsson}

\section{References}

Allen, E., McKeever, M., \& Mitchum, J. 1996. The Energy Yardstick: Using PLACE3S to Create More Sustainable Communities. Washington, DC: US Department of Energy, The Center of Excellence for Sustainable Development, and the Office of Energy Efficiency and Renewable Energy.

http://www.smartcommunities.ncat.org/pdf/places.pdf

Botkyrka Municipality. 2009. Framtid för Alby - ett långsiktigt program för hållbar utveckling. http://www.botkyrka.se/SiteCollectionDocuments/Geografiska\%2 0omr\%C3\%A5den/Utvecklingsprogram\%20f\%C3\%B6r\%20Alby.pdf

Botkyrka Municipality. 2015. Kommunfakta.

http://www.botkyrka.se/kommunochpolitik/ombotkyrka/kommu nfakta

Botkyrka Statistikportal. 2015. Områdesfakta Alby Kommundel, BOKD1 Alby.

http://botkyrka.statistikportal.se/omradesfakta/

Eskelinen, J., Robles, A.G., Lindy, I., Marsh, J., \& Muente-Kunigami, A. 2015. Citizen-Driven Innovation: A Guidebook for City Mayors and Public Administrators. World Bank, Washington, DC, and European Network of Living Labs.

http://hdl.handle.net/10986/21984

ENoLL. 2015. About Us: What is a Living Lab? European Network of Living Labs. Accessed December 1, 2015:

http://www.openlivinglabs.eu/aboutus

Elbakidze, M., Dawson, L., Andersson, K., Axelsson, R., Angelstam, P., Stjernquist, I., Teitelbaum, S., Schlyter, P., \& Thellbro, C. 2015. Is Spatial Planning a Collaborative Learning Process? A Case Study from a Rural-Urban Gradient in Sweden. Land Use Policy, 48: 270-285.

http://dx.doi.org/10.1016/j.landusepol.2015.05.001

Følstad, A. 2008. Living Labs for Innovation and Development of Information and Communication Technology: A Literature Review. The Electronic Journal for Virtual Organization \& Networks, 10: 99-131.

Häkkinen, T. 2012. Systematic Method for the Sustainability Analysis of Refurbishment Concepts of Exterior Walls. Construction and Building Materials, 37: 783-790.

http://dx.doi.org/10.1016/j.conbuildmat.2012.07.084

JPI Urban Europe. 2015a. A Cavalcade of Projects. Joint Programming Initiative Urban Europe. Accessed December 1, 2015:

http://jpi-urbaneurope.eu/projects-2/

JPI Urban Europe. 2015b. Transition towards Sustainable and Liveable Urban Futures: The Strategic Research and Innovation Agenda of Urban Europe. Joint Programming Initiative Urban Europe. Accessed December 1, 2015:

http://jpi-urbaneurope.eu/activities/sria-agenda/

Juujärvi, S., \& Pesso, K. 2013. Actor Roles in an Urban Living Lab: What Can We Learn from Suurpelto, Finland? Technology Innovation Management Review, 3(11): 22-27. http://timreview.ca/article/742

HSB Living Lab. 2015. HSB Living Lab. Accessed December 1, 2015: https://www.hsb.se/kampanjer/hsblivinglab/
Hirvikoski, T. 2014. Foreword: Special Issue on Smart Cities. Interdisciplinary Studies Journal, 3(4): 6-7.

Leminen, S. 2015. Q\&A. What Are Living Labs? Technology Innovation Management Review, 5(9): 29-35.

http://timreview.ca/article/928

Leminen, S., Westerlund, M., \& Nyström, A.-G. 2012. Living Labs as Open-Innovation Networks. Technology Innovation Management Review, 2(9): 6-11.

http://timreview.ca/article/602

McCormick, K., \& Kiss, B., 2015. Learning through Renovations for Urban Sustainability: The Case of the Malmö Innovation Platform. Current Opinion in Environmental Sustainability, 16: 44-50. http://dx.doi.org/10.1016/j.cosust.2015.06.011

McPhee, C., Tukiainen, T., Leminen, S., \& Westerlund, M. 2015. Editorial: Smart Cities and Regions. Technology Innovation Management Review, 5(10): 3-6. http://timreview.ca/article/931

Mulder, I. 2012. Living Labbing the Rotterdam Way: Co-creation as an Enabler for Urban Innovation. Technology Innovation Management Review, 2(9): 39-43. http://timreview.ca/article/607

Nevens, F. Frantzeskaki, N., Gorissen, L., \& Loorbach, D. 2013. Urban Transition Labs: Co-Creating Transformative Action for Sustainable Cities. Journal of Cleaner Production, 50 (1): 111-122. http://dx.doi.org/10.1016/j.jclepro.2012.12.001

SCB. 2015. SCB:s medborgarundersökning - våren 2015, Botkyrka kommun: Rapport. Statistiska Centralbyrån.

http://www.botkyrka.se/SiteCollectionDocuments/Medborgarund ers.\%20Rapport\%20Botkyrka\%20SCB_2015.pdf

Ståhlbröst, A. 2008. Forming Future IT - The Living Lab Way of User Involvement. Doctoral Thesis, Luleå University of Technology, Department of Business Administration and Social Sciences, Division of Informatics. 2008:62.

Thörn, P., Seitsonen, I., Karlsson, A., Federley, M., Holopainen, R., \& Sepponen, M. 2015. Selection of Urban Living Labs in Alby and Peltosaari. SubUrbanLab project deliverable D3.1 \& D3.2.

http://suburbanlab.eu/wp-

content/uploads/2015/02/SubUrbanLab_D-3-1-D-3-2_Selectionof-ULL-in-Alby-and-Peltosaari_public.pdf

Veeckman, C., Schuurman, S., Leminen, S., \& Westerlund, M. 2013. Linking Living Lab Characteristics and Their Outcomes: Towards a Conceptual Framework. Technology Innovation Management Review, 3(12): 6-15.

http://timreview.ca/article/748

Voytenko, Y., McCormick, K., Evans, J., \& Schliwa, G. (in press). Urban Living Labs for Sustainability and Low Carbon Cities in Europe: Towards a Research Agenda. Journal of Cleaner Production. http://dx.doi.org/10.1016/j.jclepro.2015.08.053

Weingaertner, C., \& Moberg, Å. 2011. Exploring Social Sustainability: Learning from Perspectives on Urban Development and Companies and Products. Sustainable Development, 22(2): 122-133. http://dx.doi.org/10.1002/sd.536 